\title{
Thymosin Beta-15A
}

National Cancer Institute

\section{Source}

National Cancer Institute. Thymosin Beta-15A. NCl Thesaurus. Code C18041.

Thymosin beta-15A (45 aa, $\sim 5 \mathrm{kDa}$ ) is encoded by the human TMSB15A gene. This protein plays a role in both actin binding and the inhibition of actin polymerization. 